\title{
ANTIMICROBIAL ACTIVITY OF TURKISH VIBURNUM SPECIES
}

\author{
M Eryilmaz ${ }^{*}$, S Ozbilgin ${ }^{1}$, B Ergene ${ }^{1}$, B SeVer Yilmaz $^{1}$, \\ ML Altun ${ }^{1}$ AND G Saltan ${ }^{1}$ \\ Department of Pharmaceutical Microbiology, Faculty of Pharmacy, Ankara University, \\ Ankara-06100, Turkey
}

Key words: Antimicrobial activity, Viburnum opulus, V. orientale, V. tinus, V. lantana

\begin{abstract}
Antimicrobial activities of aqueous and ethanolic extracts of Viburnum opulus L., V. orientale Pallas, V. tinus L. and V. lantana L. against Staphylococcus aureus ATCC 25923, S. aureus ATCC 43300 (MRSA), Bacillus subtilis ATCC 6633, Escherichia coli ATCC 25922, Pseudomonas aeruginosa ATCC 27853, Klebsiella pneumoniae RSKK 574 and Candida albicans ATCC 10231 were carried out. The disc diffusion and tube dilution techniques were used to determine the antimicrobial activities of plant extracts. The ethanolic extracts of tested species of Viburnum exhibited better antimicrobial activity than that of aqueous extracts.
\end{abstract}

The genus Viburnum L. (Caprifoliaceae) comprises more than 230 species distributed from South America to Southeast Asia, the majority of them being endemic (Lobstein et al., 1999). The plant is represented by four species in the flora of Turkey; Viburnum opulus L., V. lantana L., V. orientale Pallas, and $V$. tinus L. (Davis et al.1988).

Viburnum L. species have been reported to contain sesquiterpenoids, triterpenoids and sterols; phenolic compounds and their glycosides such as tannins, flavonoids and anthocyanins and iridoid glycosides in their stem, root and leaves, and investigated to posses uterine sedative, diuretic, cardiovascular stimulant, antimicrobial, antiinflammatory, anti-nociceptive, antispasmodic, antiasthmatic and astringent activities (Prabhu et al. 2011). Viburnum L. represented with four deciduous shrub species in Turkey (Y1lmaz et al. 2008).

In Central Anatolia, a traditional beverage named gilaburu has been prepared from the fruits of $V$. opulus whose fruits have a dark-red color and are edible. The fruits of $V$. opulus have been used as antidiabetic, and the bark of $V$. lantan $a$ has been used as rubefiant and analgesic in Turkish folk medicine (Baytop 1999). The preventive effects of $V$. dilatatum on oxidative damage were reported in rats subjected to stress (Iwai et al. 2001), and in streptozotocin-induced diabetic rats (Iwai et al. 2004). Antioxidant activity of $V$. opulus and an antihyperglycemic effect of $V$. dilatatum have also been previously noted in different systems (Andreeva et al. 2004, Iwai et al. 2006). The alcoholic extract of $V$. erubescens has been reported to show antiviral activity (Dhar et al. 1968). Some iridoid aldehydes isolated from $V$. luzonicum exhibited a moderate inhibitory activity against HeLa S3 cancer cells (Fukuyama et al. 2005).

The objective of this study was to evaluate the antimicrobial activities of aqueous and ethanolic extracts of Viburnum opulus, V. orientale, $V$. tinus and $V$. lantana against six bacteria and a yeast. To our knowledge, this is the first comprehensive investigation on the evaluation of antimicrobial activities of these four Viburnum species.

Viburnum opulus (AEF No 23696), $V$. orientale (AEF 25988), $V$. tinus (AEF 25891) and $V$. lantana (AEF No 23543) were collected in the flowering stages from Kayseri, Artvin, Aydın

*Author for correspondance: <meryilmaz@ankara.edu.tr>. ${ }^{1}$ Department of Pharmacognosy, Faculty of Pharmacy, Ankara University, Ankara-06100, Turkey. 
and Ankara (Turkey), respectively. The plants were identified by Prof. Dr Hayri Duman, Department of Biology, Faculty of Sciences, Gazi University, Voucher specimens have been deposited in the Herbarium of Faculty of Pharmacy, Ankara University.

Preparation of extracts: Stem, leaf and fruit of $V$. orientale, $V$. tinus, $V$. opulus and leaf of $V$. lantana were separated and dried. Plant materials were powdered and then $5 \mathrm{~g}$ of each were weighted for the extraction. Aqueous and ethanolic (75\%) extracts of each sample were prepared by stirring on a magnetic stirrer for $8 \mathrm{~h}$ at room temperature. The extracts were concentrated under pressure and the residues containing water were dried by lyophilisation.

Test solutions for antimicrobial activity were prepared by dissolving $10 \mathrm{mg}$ of dried extracts in their solvents (water or $75 \%$ ethanol) and poured into filling to $10 \mathrm{ml}$ in volumetric flask resulting a concentration of $1000 \mu \mathrm{g} / \mathrm{ml}$.

Staphylococcus aureus ATCC 25923, S. aureus ATCC 43300 (MRSA), Bacillus subtilis ATCC 6633, Escherichia coli ATCC 25922, Pseudomonas aeruginosa ATCC 27853, Klebsiella pneumoniae RSKK 574 and Candida albicans ATCC 10231 were used in the present investigation.

In vitro antibacterial and antifungal activities of Viburnum species: The disc diffusion method (Rangkadilok et al. 2012) and tube dilution technique were used to determine the antimicrobial activities of extracts. Minimum inhibitory concentrations (MIC) were determined with the effective Viburnum sp. extracts (Karunai-Raj et al. 2012). The extracts were sterilized through a $0.45 \mu \mathrm{m}$ membrane filter.

Disc-diffusion method: The inocula were suspended in sterile saline and diluted according to $0.5 \mathrm{McF}$ arland standard and then spread on solid culture media plates. Empty paper discs (6 mm in diameter) were soaked with $20 \mu \mathrm{l}$ of the extract $(1000 \mu \mathrm{g} / \mathrm{ml})$ and placed on the inoculated plates. These plates, after remaining $2 \mathrm{~h}$ at $4^{0} \mathrm{C}$, were incubated at $37^{\circ} \mathrm{C}$ for $24 \mathrm{~h}$. The diameters of the inhibition zones were measured in millimeters. Ampicillin $(10 \mu \mathrm{g})$, ciprofloxacin $(5 \mu \mathrm{g})$ and fluconazole $(25 \mu \mathrm{g})$ were used as standards.

Determination of minimum inhibitory concentration (MIC): Broth dilution assay was used for determination of the minimum inhibitory concentrations (MIC). The cultures were obtained in Mueller Hinton Broth (Difco) for all the bacteria after 18-24 h of incubation at $37 \pm 1^{\circ} \mathrm{C}$ and for C. albicans in Saboraud Dextrose Broth (Difco) after incubation for $48 \mathrm{~h}$ at $25 \pm 1^{\circ} \mathrm{C}$. Serial twofold dilutions ranging from 500 to $31.25 \mu \mathrm{g} / \mathrm{ml}$ were prepared in medium. A set of tubes containing only inoculated broth were used as controls. After incubation for $18-24 \mathrm{~h}$ at $37 \pm 1{ }^{\circ} \mathrm{C}$ for bacteria and $48-72 \mathrm{~h}$ at $25 \pm 1^{\circ} \mathrm{C}$ for C. albicans, the last tube with no microbial growth was recorded to represent $\mathrm{MIC}(\mu \mathrm{g} / \mathrm{ml})$.

Table 1 represents the in vitro antimicrobial activities of aqueous and ethanolic extracts of Viburnum sp. against six bacteria and C. albicans by disc diffusion method. Ethanolic extracts prepared from Viburnum sp. showed antimicrobial activity against all the tested microbes. It was observed that the ethanolic extracts of leaf and stem of $V$. opulus, fruit of $V$. orientale, leaf, fruit and stem of $V$. tinus showed activity against $S$. aureus and MRSA (S. aureus ATCC 43300); fruit of $V$. orientale showed activity against $B$. subtilis; leaf and fruit of $V$. opulus, fruit and stem of $V$. orientale, fruit of $V$. tinus, leaf of $V$. lantana showed activity against $E$. coli, $P$. aeruginosa, $K$. pneumoniae; leaf of $V$. orientale and $V$. tinus showed activity against $E$. coli, $K$. pneumoniae, stem of $V$. orientale showed activity against $C$. albicans. No antimicrobial activity was observed against S. aureus, MRSA, B. subtilis, E. coli, $P$. aeruginosa and C. albicans for the aqueous extracts but aqueous extracts of leaf of $V$. opulus, $V$. orientale, $V$. tinus, $V$. lantana showed weak antibacterial activity against $K$. pneumoniae. These extracts possessed activity having MIC values of 125-250 $\mu \mathrm{g} / \mathrm{ml}$ against the tested microorganisms (Table 2). The activity of the extracts of Viburnum sp. 


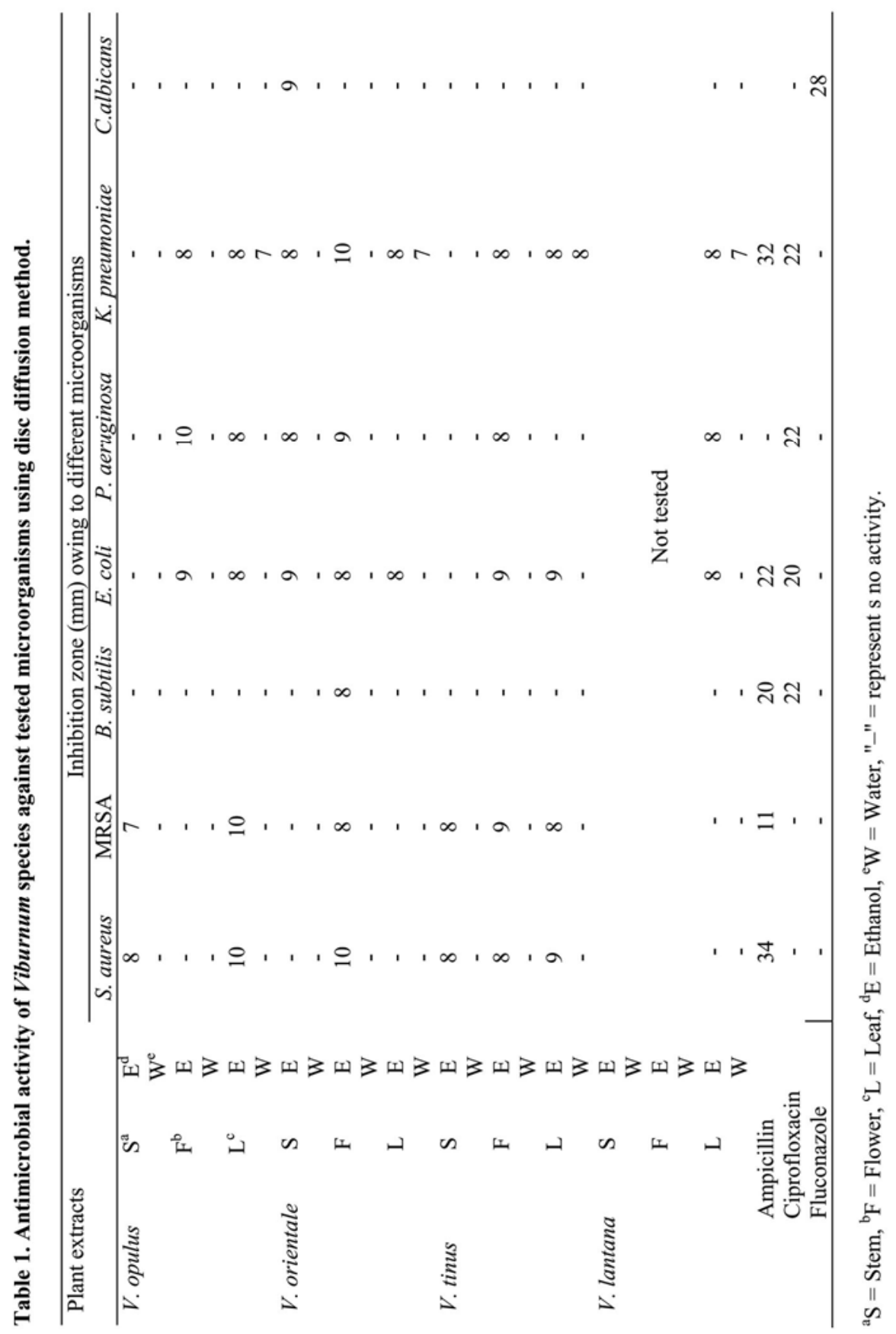




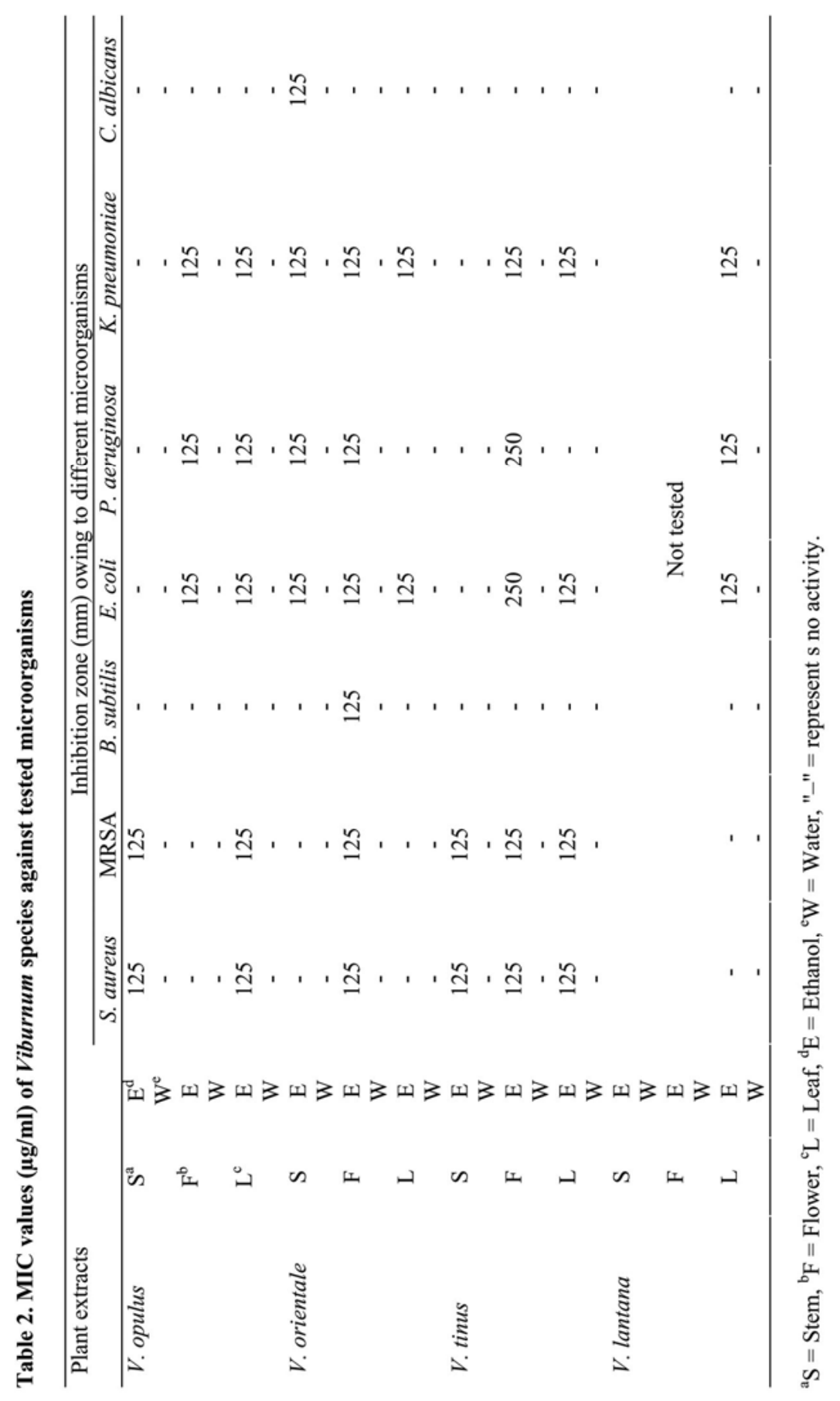


was less than that of the standards. The ethanolic extracts of four tested Viburnum species exhibited better antimicrobial activity compared to aqueous extracts.

A preliminary organic analysis on the alcoholic stem extracts showed the presence of phenolic compounds such as flavonoids, tannins, anthocyanins, phenolic acids and their derivatives (glycosides) as their principal constituents, which may be attributed to a mild and pronounced antibacterial activities of the extracts (Prabhu et al. 2011).

Yllmaz et al. (2008) investigated the antimicrobial activities of essential oils (in hexane) of $V$. opulus, $V$. lantana and $V$. orientale against the bacteria E. coli ATCC 25922, K. pneumoniae ATCC 13883, P. aeruginosa ATCC 10145, E. faecalis ATCC 29212, S. aureus ATCC 25923, B. cereus 709 Roma and the fungus $C$. tropicalis ATCC 13803 and observed no activity against all the test microorganisms for $V$. opulus and $V$. lantana however the essential oil of the $V$. orientale showed weak antibacterial activity against Gram-positive bacteria. In another study Ucar-Turker et al.(2012) evaluated the antibacterial activity of fruit extracts of $V$. lantana and they indicated that the hot ethanolic extract of $V$. lantana showed better antibacterial activity than the cold ethanolic extract against $S$. aureus, S. epidermidis and S. pyogenes.

From this findings it could be concluded that, the ethanolic extracts of Viburnum sp. exhibited antimicrobial activity against the tested microorganisms.

\section{References}

Andreeva TI, Komarova EN, Yusubov MS and Korotkova EI 2004. Antioxidant activity of cranberry tree (Viburnum opulus L.) bark extract. Pharmaceut. Chem. J. 38: 548-550.

Baytop T 1999. Türkiye'de Bitkilerle Tedavi [Therapy with medicinal plants in Turkey], Nobel Tip Kitabevleri, Istanbul. p. 210.

Davis PH, Mill RR and Tan K 1988. Flora of Turkey and the East Aegean Islands, 10 (Supplement), Edinburgh University Press, Edinburgh. p. 154.

Dhar ML, Dhar MM, Dhawan BN, Mehrotra BN and Ray C 1968. Screening of Indian plants for biological activity. Indian J. Exp. Biol. 6: 232-247.

Fukuyama Y, Kubo M, Minami H, Yuasa H, Matsuo A, Fujii T, Morisaki M and Harada K 2005. Rearranged vibsane-type diterpenes from Viburnum awabuki and phytochemical reaction of Vibsanin B. Chem. Pharm. Bull. 53: 72-80.

Iwai K, Kim MY, Onodera A and Matsue H 2006. A-Glucosidase inhibitory and antihyperglycemic effects of polyphenols in the fruit of Viburnum dilatatum Thunb. J. Agric. Food Chem. 54: 4588-4592.

Iwai K, Onodera A and Matsue H 2001. Antioxidant activity and inhibitory effect of Gamazumi (Viburnum dilatatum THUNB.) on oxidative damage induced by water immersion restraint stress in rats. Int. J. Food Sci. Nutr. 52: 443-451.

Iwai K, Kim MY, Onodera A and Matsue H 2004. Inhibitory effects of Viburnum dilatatum Thunb. (gamazumi) on oxidation and hyperglycemia in rats with streptozocin-induced diabetes. J. Agric. Food Chem. 52:1002-1007.

Karunai-Raj M, Balachandran C, Duralpandiyan V, Agastian P and Ignacimuthu S 2012. Antimicrobial activity of Ulopterol isolated from Toddalia asiatica (L.) Lam: A traditional medicinal plant. J. Ethnopharmacol. 140:161-165.

Lobstein, A, Haan-Archipoff G, Englert J, Kuhry J and Anton R 1999. Chemotaxonomical investigation in the genus Viburnum. Phytochemistry. 50:1175.

Prabhu K, Karar PK, Hemalatha S and Ponnudurai K 2011. Biological and Phytochemical investigations recently carried out on three Viburnum Linn. species - An overview. Int. J. Pharm. \& Ind. Res. 1: 219-241. 
Rangkadilok N, Tongchusak S, Boonhok R, Chaiyaroj SC, Junyaprasert VB, Buajeeb W, Akanimanee J, Raksasuk T, Suddhasthira T and Satayavivad J 2012. In vitro antifungal activities of longan (Dimocarpus longan Lour) seed extract. Fitoterapia. 83: 545-553.

Uçar-Türker A, Birinci-Yıldırım A and Pehlivan-Karakaş F 2012. Antibacterial and Antitumor Activities of Some Wild Fruits Grown in Turkey. Biotechnol. \& Biotechnol. EQ. 26: 2765-2772.

Yılmaz N, Yaylı N, Mısır G, Coşkunçelebi K, Karaoğlu Ş and Yaylı N 2008. Chemical composition and antimicrobial activities of the essential oils of Viburnum opulus, Viburnum lantana and Viburnum orientala. Asian J. Chem. 20:3324-3330.

(Manuscript recieved on 10 April, 2012; revised on 14 July, 2013) 